\title{
Узагальнення досвіду роботи в питаннях вдосконалення кидкових елементів з обручем юних спортсменок у художній гімнастиці
}

\author{
Алла Семизорова \\ Інна Красова ${ }^{1}$ \\ Ксенія Шевченко ${ }^{2}$
}

\author{
Харківська державна академія фізичної культури, \\ Харків, Україна ${ }^{1}$ \\ Спортивний Клуб «Академія гімнастики Кристал», \\ м. Щецин, Польща ${ }^{2}$
}

Мета: узагальнити тренерський досвід щодо вдосконалення кидкових елементів з обручем гімнасток 7-8 років.

Матеріал і методи: в дослідженні брали участь 120 спортсменок 7-8 років, які тренуються в ДЮСШ з художньої гімнастики міста Харкова та міста Щецин. Рівень володіння кидковими рухами обручем визначався за допомогою характерних рухових тестів із застосуванням відеозапису. Оцінювання змагальної вправи проводилося методом експертних оцінок. Експертами були тренери, які мали суддівську категорію з художньої гімнастики. Результат визначався відповідно до правил змагань. Максимальна оцінка - 10,0 балів.

Результати: виявлено рівень володіння базовими кидковими елементами з обручем гімнасток 7-8 років, обгрунтовано методику виправлення помилок. Найнижчі оцінки гімнастки отримали за наступними тестами: «Кидок обруча, що лежить на підлозі, махом ногою з обертанням навколо діаметральної вісі, ловля в стрибок через обруч» ( $\bar{X}$ - 6,2 балів); «Кидок предмета з обертання в бічній площині лівою рукою» ( $\bar{X}-$ 7,0 балів); «Кидок махом горизонтально розташованого обруча, «шене», ловля в прохід в переворот боком» ( $\bar{X}-7,5$ балів).

Висновки: найнижчі результати отримано при виконанні елементів «труднощів», «ризиків», «майстерності» та при виконанні кидків лівою рукою. Результат за виконання змагальної вправи з обручем - 7,2 балів. Повторні результати кидкових дій з обручем збільшились від 7\% до 31\% і становлять від 8, 1 балів до 9,5 балів. За виконання змагальної вправи з обручем результат збільшився на 18\% і становить 8,5 балів.

Ключові слова: обруч, гімнастика, художня, кидки, досвід, тренер, корекція.

\section{Вступ}

Художня гімнастика є складнокоординаційним видом спорту, змагальна програма в якому вимагає від гімнасток наявності широкого кола вмінь та навичок. Загальновідомо, що відмінною рисою художньої гімнастики, як виду спорту, є виконання вправ з предметами. Гімнастки в змагальних композиціях крім володіння своїм тілом, одночасно демонструють віртуозну техніку виконання елементів с м'ячем, скакалкою, стрічкою, булавами та обручем $[4 ; 6 ; 11 ; 12]$. Висока складність змагальних вправ в художній гімнастиці зумовлює пошук ефективних педагогічних підходів у процесі вдосконалення технічної підготовки спортсменок, в тому числі у вправах 3 предметами [5; 8, 16]. Для досягнення майстерності спортсменкам необхідно навчитися виконувати кидки, відбиви, перекати, обертання, фігурні рухи і різні маніпуляції з предметами. Вражаючими при виконанні і важкими в навчанні $€$ кидкові рухи, які виконуються всіма предметами [7; 13]. Засвоєння вправ з предметами юні гімнастики починають на першому році навчання.

У віці 7-8 років юні гімнастки до базових навичок, що були вже вивчені, додають більш складні елементи [4; 9]. На даному етапі підготовки важливо скорегувати неточності техніки в набутих базових навичках, попередити можливі помилки в освоєнні складних елементів, одними з яких є кидкові рухи з обручем.
Зв'язок дослідження з науковими, практичними завданнями, планами, програмами. Дослідження проводилося відповідно до ініціативної теми наукового дослідження кафедри гімнастики, танцювальних видів спорту, та хореографії ХДАФК: «Теоретико-методологічні основи розвитку системоутворюючих компонентів фізичної культури (спорт, фітнес і рекреація)» на 2020-2025 рр. , номер державної реєстрації $0120 \mathrm{U} 101215$.

Мета дослідження - узагальнити тренерський досвід щодо вдосконалення кидкових елементів з обручем гімнасток 7-8 років.

Завдання дослідження: 1) виявити рівень володіння кидковими елементами з обручем гімнасток 7-8 років; 2) розробити методику корекції помилок кидкових рухів з обручем.

\section{Матеріал і методи дослідження}

У дослідженні брали участь 120 спортсменок 7-8 років, які тренуються у ДЮСШ з художньої гімнастики міста Харкова та міста Щецин. Рівень володіння кидковими рухами обручем визначався за допомогою характерних рухових тестів із застосуванням відеозапису. Оцінювання змагальної вправи проводилося методом експертних оцінок. Експертами були тренери, які мали суддівську категорію з художньої гімнастики. Максимальна оцінка за кожний тест і змагальну вправу - 10,0 балів. Зняття балів здійснювалось 


\section{СЛОБОЖАНСЬКИЙ НАУКОВО-СПОРТИВНИЙ ВІСНИК}

відповідно з вимогами до техніки виконання вправ згідно з правилами змагань з виду спорту $[11 ; 12 ; 13]$.

\section{Результати дослідження}

Гімнастки досліджуваної групи освоїли раніше деякі базові навички виконання елементів з обручем. Навчання кидків з обручем починалось під час розучування базових елементів з предметами. В даний час юні спортсменки розучують більш складні елементи, які дають можливість отримати додаткові бали за «труднощі», «ризики» та «майстерність».

Для визначення рівня підготовленості гімнасток були визначені тести з різними видами кидкових елементів обручем, які найчастіше складають зміст змагальних програм і є доступними для освоєння в даному віці [2; 3; 12; 13].

Гімнасткам було запропоновано вісім тестових завдань, у яких вони виконували високі кидки обручем в різних площинах, без обертань та з обертанням, кидки та ловлі без зорового контролю та без допомоги рук. Перші два кидки над собою з обертання в бічній площині [2; 7; 8; 13] гімнастки виконували з обертання обруча попереду на відведеній назовні кисті, рука вперед. В наступних двох тестах ці кидки виконувалися без зорового контролю.

У наступній п'ятій тестовій вправі спортсменки виконували кидок вперед-вгору вертикально розташованого обруча махом рукою з виконанням «шене» під предметом та ловлею увільний хват за нижній край обруча в перевороті боком.

Шостою тестовою вправою був кидок обруча над собою з обертанням навколо діаметральної горизонтально розташованої вісі та ловлею без допомоги рук в прохід в обруч. 3 вихідного положення - обруч вперед горизонтально хватом двома руками знизу, спортсменки махом виконували високий кидок обруча з обертанням до себе. Ловля здійснювалась на тіло спортсменки без допомоги рук, в прохід в обруч ногами в сіді кутом на підлозі з подальшим хватом зверху двома руками в перекиді назад.

Сьомою вправою був кидок горизонтально розташованого обруча вперед-вгору махом двома руками, «шене» та ловля без допомоги рук в прохід в обруч у переворот боком. 3 вихідного положення - обруч вперед горизонтально хватом двома руками знизу: обруч в сторону-до низу, махом кидок вперед-вгору з наступним виконанням «шене» під предметом. Ловля здійснювалась на тілі спортсменки без допомоги рук в прохід в обруч переворотом боком.

Восьма вправа:на перевороті боком кидок обруча, що лежить на підлозі, махом ногою з обертанням навколо діаметральної вісі предмета, ловля руками в стрибок через обруч. У вихідному положенні - обруч лежить на опорній нозі, протилежна вільна сторона обруча на підлозі, гімнастка переступає через обруч і при виконанні перевороту махом опорної ноги здійснює кидок обруча з обертанням до себе навколо вісі у площині предмета, ловля виконується руками у стрибку через обруч.

На виконання кожного тесту спортсменкам відводилося три спроби, записувався кращий результат. Було розраховано середні значення в групі. Гімнастки виконували змагальну програму з обручем на оцінку (табл. 1).

Таблиця 1

Результати тестування кидкових дій з обручем (max - 10 балів, n-120)

\begin{tabular}{|c|c|c|c|}
\hline Тести & $\begin{array}{l}\text { Середнє } \\
\text { значення } \\
\quad \bar{X}\end{array}$ & $\begin{array}{c}\text { Стандартне } \\
\text { відхилення } \\
\sigma\end{array}$ & $\begin{array}{c}\text { Коефіцієнт } \\
\text { варіації } \\
\text { V }\end{array}$ \\
\hline $\begin{array}{l}\text { 1. Кидок } 3 \text { обертанням в бічній площині } \\
\text { правою рукою }\end{array}$ & 8,8 & 1,17 & 13 \\
\hline $\begin{array}{l}\text { 2. Кидок } 3 \text { обертанням в бічній площині } \\
\text { лівою рукою }\end{array}$ & 7,8 & 1,42 & 18 \\
\hline $\begin{array}{l}\text { 3. Кидок правою рукою із заплющеними } \\
\text { очима, ловля з розплющеними }\end{array}$ & 8,6 & 1,24 & 14 \\
\hline $\begin{array}{l}\text { 4. Кидок лівою рукою із заплющеними } \\
\text { очима, ловля з розплющеними }\end{array}$ & 7,0 & 1,83 & 26 \\
\hline $\begin{array}{l}\text { 5. Кидок в бічній площині, «шене», ловля в } \\
\text { переворот боком }\end{array}$ & 8,2 & 1,12 & 14 \\
\hline $\begin{array}{l}\text { 6. Кидок горизонтально розташованого } \\
\text { обруча } 3 \text { обертанням до себе, ловля без } \\
\text { допомоги рук в прохід в обруч ногами в } \\
\text { перекиді назад }\end{array}$ & 7,9 & 2,42 & 31 \\
\hline $\begin{array}{l}7 . \text { Кидок горизонтально розташованого } \\
\text { обруча, «шене», ловля без допомоги рук в } \\
\text { прохід в обруч переворотом боком }\end{array}$ & 7,5 & 1,84 & 25 \\
\hline $\begin{array}{l}\text { 8. Кидок обруча, що лежить на підлозі махом } \\
\text { ногою } 3 \text { обертанням на перевороті боком, } \\
\text { ловля руками в стрибок через обруч }\end{array}$ & 6,2 & 1,8 & 29 \\
\hline 9. Змагальна композиція з обручем & 7,2 & 1,86 & 26 \\
\hline
\end{tabular}


Результати тестування виявили, що гімнастки при виконані вправ допускали помилки. При розробці методики корекції кидкових рухів з обручем увага зверталась на попередження помилок, корегування та удосконалення техніки виконання вправ.

В кидках з обертанням в бічній площині правою та лівою рукою необхідно відзначити, що виконання даної вправи правою рукою було значно краще (8,8 балів та 8,6 балів), ніж лівою (7,8 балів та 7,0 балів), навіть при виконанні кидка правою рукою без зорового контролю. В методиці корекції кидкових рухів з обручем обов'язково передбачалося симетричне виконання всіх завдань відповідно до вимог виду спорту, гімнастки повинні демонструвати вміння виконувати вправи обома руками. В цілому у цих кидках гімнастки частіше допускали такі помилки: невідповідна площина обруча в польоті, недостатня висота польоту предмету. В методику корекції помилок були включені наступні вправи: 1) імітація виконання кидка та ловлі без предмету; 2) виконання передкидкових дій з обертанням обруча на кисті руки; 3) кидок обруча на різну висоту.

Результати виконання кидка в бічній площині, «шене», ловля в переворот боком ( $\bar{X}$ - 8,2 балів; V-14\%) вказують на реальні можливості володіння технікою цієї вправи гімнастками 7-8 років. Однак, деякими спортсменками були допущені наступні помилки: пауза між ловлею та виконанням перевороту боком, зайві кроки перед ловлею, недостатня висота польоту предмету, неправильна площина обруча в польоті, ловля обруча двома руками. В методику корекції помилок були включені наступні вправи: 1) імітація виконання кидка та ловлі без предмету; 2) кидок вперед-вгору, два кроки, ловля в перевороті боком; 3) ловля в переворот боком після низького кидка. При виконанні кидка горизонтально розташованого обруча з обертанням до себе, ловлі без допомоги рук в прохід в обруч ногами в перекиді назад ( $\overline{\mathrm{X}}$ - 7,9 балів; V-31\%) гімнастки допускали такі помилки: неправильна вісь обертання обруча, допомога руками при ловлі, кроки перед ловлею. В методику корекції помилок були включені наступні вправи: 1) імітація виконання кидка та ловлі без предмету; 2) кидки горизонтально розташованого обруча з обертанням до себе; 3) ловля в прохід в перекиді назад після низького кидка.

Виконання кидка горизонтально розташованого обруча, «шене», ловля без допомоги рук в прохід в обруч переворотом боком юним гімнасткам дається складно ( $\bar{X}-7,5$ балів; V-25\%). При виконанні ціеї вправи спортсменки допускали наступні помилки: неправильна площина обруча в польоті, недостатня висота кидка, пауза між ловлею та виконанням перевороту боком. Для виправлення помилок в методику були включені наступні вправи:1) імітація виконання кидка та ловлі без предмету; 2) махи з обручем з виконанням передкидкових дій; 3) кидок махом вперед-вгору без виконання «шене» та ловля в переворот боком; 4) ловля в прохід в переворот боком після низького кидка. Найнижчі оцінки гімнастки отримали за виконання кидка ногою з обертанням до себе навколо горизонтально розташованої вісі предмета на перевороті боком, ловлі в стрибок через обруч ( $\bar{X}$ - 6,2 балів; V-29\%). Гімнастки при виконанні тесту допускали наступні помилки: обруч зісковзував з ноги при виконанні викиду на перевороті боком, неправильна площина предмету в польоті, виконання кидка з над- мірною інтенсивністю, велика відстань між викидом та ловлею предмета. Для виправлення помилок в методику були включені такі вправи: 1) мах ногою з обручем на нозі з вихідного положення як при викиді обруча на перевороті боком; 2) кидок ногою на перевороті боком з середньою висотою з акцентом на збереження правильної площини предмета; 3) ідіомоторне виконання цілісної вправи.

Для корекції помилок при виконанні базових елементів з обручем і підвищення результативності кидків гімнастки виконували різноманітні утримання, обертання, перекати, маніпуляції, махи і безпосередньо різні кидки обруча [1; 2; 3; 13].

Змагальна композиція з обручем була останнім тестом, під час якого визначалось наскільки ефективно вищезазначені вправи гімнастки виконують в своїх композиціях. Середнє значення - 7,2 балів, коефіцієнт варіації - 26\% вказує на необхідність вдосконалення виконання кидкових елементів «труднощів» і «ризиків».

В ході експерименту, під час предметної розминки, гімнастки, за вказівками тренера, проводили розминку в інтенсивному, швидкому темпі, тим самим скорочуючи іï. Завдяки цьому звільнилися 15 хвилин і дівчата виконували додатково деякі види кидків, що склало 45 хвилин роботи на тиждень. Методика була застосована на протязі двох місяців (360 хв., або 6 годин). На тренуванні 3 предметом більше уваги приділялось тим вправам, які найгірше були оцінені в тесті. Гімнасткам пояснювались вузлові моменти техніки виконання кожного кидкового руху. За допомогою відеозапису та наочно порівнювалось правильне та неправильне виконання вправ. Правильне виконання закріплялось великою кількістю повторень з обов'язковим свідомим контролем усіх деталей техніки та з послідуючим контролем вправи. За необхідністю процедура корекції помилок повторювались на наступних тренуваннях. Виконання вправ перед змагальною композицією дозволяло краще підготувати гімнасток до роботи з предметом, вони робили менше втрат і технічних помилок.

Після застосування методики проводились повторні тести, які виявили, що гімнастки значно підвищили свій рівень володіння обручем. Повторні результати кидкових дій з обручем становлять від 8,1 балів до 9,2 балів.

Покращення результатів відзначалося в тесті «кидок ногою з обертанням на перевороті боком, ловля в стрибок через обруч». Під час першого тестування гімнастки, як правило, випробовували дану вправу, тому й результат був в групі низьким та неоднорідним. В ході впровадження методики велика увага приділялася усуненню помилок та вдосконаленню техніки виконання даного кидка. Після застосування методики спортсменки почали виконувати вправу з кращою технікою: без втрати предмету, з достатньою висотою та з правильною площиною предмета в польоті, з гарною ловлею. В повторному тестуванні більшість гімнасток виконали дану вправу досить впевнено, середній результат в групі склав 8,1 балів, коефіцієнт варіації зменшився з 30 \% до 15 \% (рис. 1).

У наступних, проблемних для гімнасток, тестах, зокрема у кидках лівою рукою в бічній площині з обертанням, результат покращився з 7,0 балів до 8,7 балів та 3 7,8 балів до 8,8 балів. Гімнастки після застосування методики почали виконувати вправу з достатньою висотою польоту предмета та без зайвих кроків. 
Кидок $з$ обертанням в бічній площині правою рукою

Кидок з обертанням в бічній площині лівою рукою

Кидок правою рукою із заплющеними очима, ловля 3 розплющеними

Кидок лівою рукою із заплющеними очима, ловля 3 розплющеними

Кидок в бічній площині, «шене», ловля в переворот боком

Кидок горизонтально розташованого обруча 3

обертанням ловля в прохід ногами в перекиді назад

Кидок горизонтально розташованого обруча, «шене», ловля в прохід переворотом боком

Кидок ногою $з$ обертанням на перевороті боком, ловля в стрибок через обруч

Змагальна композиція з обручем$$
\text { (1) }
$$

彗Початкові результати 曰Повторні результати

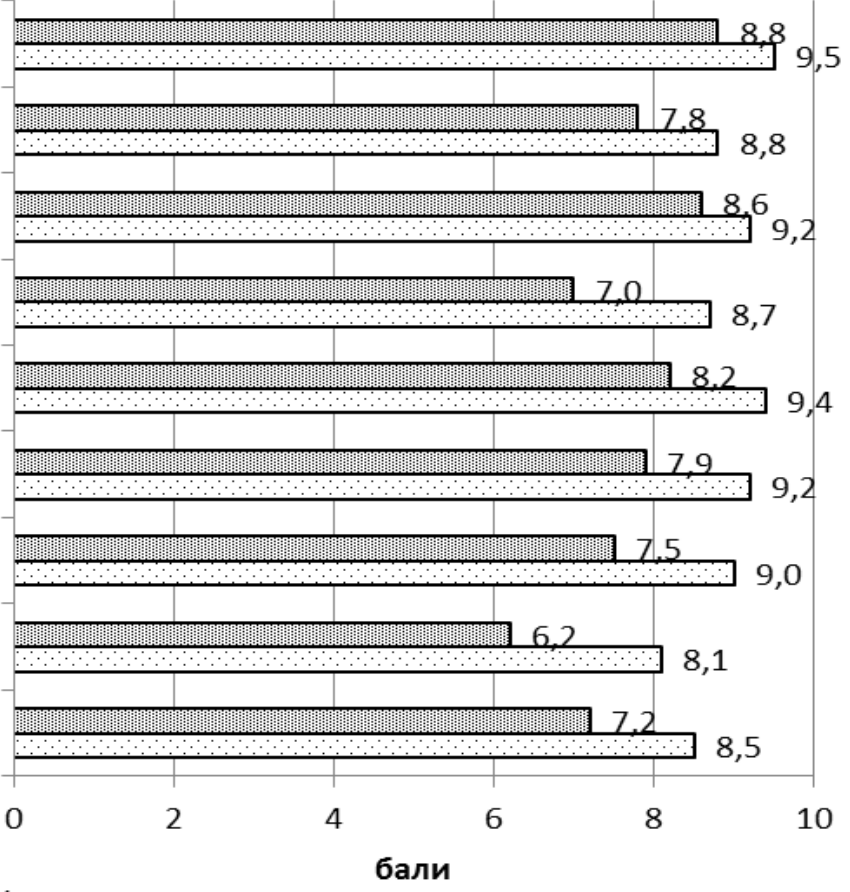

Рис. 1. Зміни у результатах кидкових дій з обручем у наступному, проблемному для гімнасток, тесті «кидок махом горизонтально розташованого обруча без обертань, «шене», ловля в прохід в переворот боком» результат збільшився від 7,5 балів до 9,0 балів, що відповідає покращенню на 20\%. Гімнастки після застосування методики почали виконувати вправу більш впевнено та з мінімальними помилками.

Найменше покращення (7\% й 8\%) виявилося в кидках з обертанням в бічній площині правою рукою. Це пов'язано з тим, що в початковому тестуванні при виконанні даної вправи спортсменки показали високий результат, тому після застосування методики спортсменки підвищили свій рівень, але з незначним приростом. При виконанні змагальної композиції з обручем результат збільшився на 18\%, що підтверджує вплив розробленої методики на поліпшення техніки виконання елементів «труднощів», «ризиків», «майстерності» у гімнасток 7-8 років.

\section{Висновки / Дискусія}

Проведені дослідження підтвердили інформацію В.Ленишин, В.Сосіної, Г.А. Топол [6; 12] стосовно того, що однією з особливостей розвитку сучасної художньої гімнастики є неухильне зростання технічної майстерності гімнасток і труднощі їх змагальних програм. На етапі попередньої базової підготовки перспективні шляхи покращення результату фахівці передусім пов'язують з навчанням елементам підвищеної труднощі, в тому числі й кидковим елементам з обручем $[1 ; 15]$. Проведене дослідження підтверджує дані Andreieva N, Zhyrnov O. [14], A. Mullagildina, I. Krasova [16], що на даному етапі підготовки важливо скорегувати помилки в техніці базових елементів та попередити їх при навчанні складних елементів, одними з яких є кидкові рухи з обручем. Аналіз результатів тестів, що виявляли рівень володіння кид- ковими рухами з обручем гімнастками 7-8 років, свідчить, що на даному етапі підготовки юні спортсменки допускають помилки при виконанні кидкових елементів з обручем. Найнижчі результати юні спортсменки продемонстрували при виконанні елементів «труднощів», «ризиків», «майстерності» ( $\bar{X}-6,2$ балів; $\bar{X}-7,5$ балів) та виконанні кидків лівою рукою ( $\bar{X}-7,0$ балів; $\bar{X}-7,8$ балів). Середній результат за виконання змагальної композиції з обручем - 7,2 балів.

Також ми згодні з твердженням фахівців $[1 ; 6 ; 7 ; 10]$ про те, що в даний час значно зріс обсяг кидкових елементів в змагальних комбінаціях гімнасток, підвищилася їх структурна складність, збільшилася амплітуда виконання, ускладнилися умови ловлі. Це зумовлює необхідність пошуку нових шляхів та можливостей, за допомогою яких можна краще та швидше навчити гімнасток управляти своїми рухами. 3 урахуванням результатів тестування спортсменок була розроблена методика корекції кидкових рухів з обручем, в результаті впровадження якої спортсменки стали виконувати кидкові елементи на кращому технічному рівні з мінімальними втратами. Результат за виконання змагальної композиції 3 обручем покращився до 8,5 балів.

Підтверджені висновки Т.С. Лисицької, Л.А. Новікової [7], А.Я. Муллагільдіної, К.О. Шевченко [9], В. R. Agostini, L.A. Novikova [14] та інших науковців, що впровадження в навчально-тренувальний процес методики вдосконалення кидкових дій предметами є одним із найбільш перспективних напрямків технічної підготовки спортсменок у художній гімнастиці.

Перспективи подальших досліджень у даному напрямку полягають у подальшому визначенні методичних підходів до корекції кидкових дій предметами спортсменок в художній гімнастиці. 
Конфлікт інтересів. Автори заявляють, що немає конфлікту інтересів, який може сприйматися як такий, що може завдати шкоди неупередженості статті.

Джерела фінансування. Ця стаття не отримала фінансової підтримки від державної, громадської або комерційної організації.

\section{Список посилань}

1. Агостини Б. Р., Новикова Л. А. (2014), «Надежность выполнения бросковых элементов без визуального контроля в художественной гимнастике», Физическая культура: воспитание, образование, тренировка: Детский тренер: журнал в журнале, № 5, С. 45-46.

2. Андрєєва Р. І. (2011), Технологія навчання техніки вправ з обручем на основі спеціальної фізичної підготовки юних гімнасток: автореф. дис. на здобуття наук. ступеня канд. наук з фіз. виховання та спорту : спец. 24.00 .01 / Харківська державна академія фізичної культури. Харків, 20 с.

3. Андреева Н. О. (2011), «Совершенствование методики обучения технике бросков и ловли гимнастических предметов на этапе специализированной базовой подготовки», Физическое воспитание студентов творческих специальностей, № 4, С. 3-5.

4. Білокопитова Ж. А., Нестерова Т. В, Дерюгіна А. М, Безсонова В. А. (1999), Художня гімнастика. Навч. прогр. для дитячо-юнацьких спортивних шкіл, спеціалізованих дитячо-юнацьких шкіл олімпійського резерву, шкіл вищої спортивної майстерності. Київ, $115 \mathrm{c}$

5. Краева Е. С., Степанова И. А. (2017), «Взаимосвязь качества выполнения перебросок в групповых упражнениях художественной гимнастики со специально-двигательными способностями спортсменок», Ученые записки университета им. П.Ф. Лесгафта, №1(143), С. 95-98.

6. Ленишин В., Сосіна В. (2014), «Особливості суддівства групових та індивідуальних вправ з художньої гімнастики», Спортивна наука України, №5 (63), С. 41-46.

7. Лисицкая Т. С., Новикова Л. А. (2017), «Обучение сложным бросковым элементам в художественной гимнастике», Фундаментальные и прикладные исследования физической культуры, спорта: традиции и инновации: материалы I Всероссийской научно-практической конференции. Москва, С. 485-493.

8. Маркова О. В., Виноградова Л. С. (2018), «Біомеханічна характеристика елементів техніки спортивних вправ у художній гімнастиці», Фізичне виховання і спорт в навчальних закладах України на сучасному етапі: стан, напрямки та перспективи розвитку: зб. наук. праць XXIV Всеукраїнської науково-практичної конференції Центральн. укр. держ. пед. ун-ту ім. В. Винниченка / ЦДПУ ім. В. Винниченка. Кропивницький; Харків: ФОП Озеров Г. В. Вип. 24, С. 261-265.

9. Муллагільдіна А. Я., Шевченко К. О. (2014), «Корекція кидкових рухів м'ячем у спортсменок 7-9 лет в художній гімнастики», Фізична культура, спорт та здоров'я: матеріали 14-й Міжнародній науково-практичної конференції, ХДАФК, С. $104-108$.

10. Муллагільдіна А. Я., Красова І. В. (2018), «Технічна підготовка спортсменок 10-11 років в художній гімнастиці у вправах з булавами», Науковий часопис Національного педагогічного університету імені М.П. Драгоманова. Серія 15: Науково-педагогічні проблеми фізичної культури (фізична культура і спорт), №. 4, С. 114-118.

11. Технічний комітет з художньої гімнастики: FIG (2017), Правила змагань з художньої гімнастки (2017-2020). URL: http:// vfrg.ru/upload/iblock/dbf/dbf6d760bc71ff64006d3431e5734407.pdf

12. Топол Г. А. (2017), Комплексна оцінка підготовленості кваліфікованих спортсменок у художній гімнастиці: автореф. дис.... канд. наук з фіз. виховання і спорту: спец. 24.00.01» Олімпійський та професійний спорт» Нац. ун-т фіз. виховання і спорту України. Київ, 24 с.

13. Художественная гимнастика (2003): учебник для тренеров, преподавателей и студ. физ. культуры / Всерос. федерация художествен. гимнастики; СПбГАФК им. П.Ф. Лесгафта; под ред. Л.А. Карпенко. М., 384 с.

14. Agostini B. R., Novikova L. A. (2014), «Identification of factors affecting the implementation jf elements of release with no eye contact in rhythmic in athletes oft he city of fortress», Journal of international federation of physical education, № 84, pp. 128-130.

15. Andreieva N, Zhyrnov O. (2019), «Features of the kinematic structure of throwing technique and catching ball in artistic gymnastics at the stage of preliminary basic training», Theory and Methods of Physical education and sports, №3, pp. 70-73 DOI:10.32652/tmfvs.2019.3.70-73

16. Mullagildina A., Krasova I. (2019), «Improving the technical training of athletes 10-11 years old in rhythmic gymnastics in exercises with clubs», Slobozhanskyi herald of science and sport, №. 1 (69), pp. 19-24.

Стаття надійшла до редакції: 02.08.2021 р.

Опубліковано: 31.08.2021 p.

Аннотация. Алла Семизорова, Инна Красова, Ксения Шевченко. Обобщение опыта работы в вопросах усовершенствования броскових элементов с обручем юных спортсменок в художественной гимнастике. Цель: обобщить тренерский опыт по совершенствованию бросковых элементов с обручем гимнасток 7-8 лет. Материал и методы: в исследовании приняли участие 120 спортсменок 7-8 лет, тренирующихся в ДЮСШ по художественной гимнастике города Харькова и города Щецин. Уровень владения бросковыми движениями обручем определялся с помощью характерных двигательных тестов и применением видеозаписи. Оценка соревновательного упражнения проводилась методом экспертных оценок. Экспертами были тренеры, имеющие судейскую категорию по художественной гимнастике. Результат определялся в соответствии с правилами соревнований. Максимальная оценка - 10,0 баллов. Результаты: выявлен уровень владения базовыми бросковыми элементами с обручем гимнасток 7-8 лет, обоснована методика исправления ошибок. Самые низкие оценки гимнастки получили в следующих тестах: «Бросок лежачего на полу обруча махом ногой с вращением вокруг диаметральной оси предмета на перевороте боком, ловля в прыжок через обруч» ( $\overline{\mathrm{X}}-6,2$ балла); «Бросок с вращения в боковой плоскости левой рукой» ( $\overline{\mathrm{X}}$-7,0 балла); «Бросок махом горизонтально расположенного обруча, «шене», ловля в проход в переворот боком» ( $\overline{\mathrm{X}}-7,5$ балла). Выводы: самые низкие результаты получены при выполнении элементов «трудностей», «рисков», «мастерства» и при выполнении бросков левой рукою. Результат за выполнение соревновательного упражнения с обручем - 7,2 балла. Повторные результаты бросковых действий с обручем увеличились от 7\% до 31\% и составляют от 8, 1 балла до 9,5 бала. За выполнение соревновательного упражнения с обручем результат увеличился на 18\% и составляет 8,5 балла.

ключевые слова: обруч, гимнастика, художественная, броски, опыт, тренер, коррекция.

Семизорова, А., Красова, І., Шевченко, К. (2021), «Узагальнення досвіду роботи в питаннях вдосконалення кидкових елементів з обручем юних спортсменок у художній гімнастиці»
Слобожанський науково-спортивний вісник, № 4(84), С. 24-30, doi:10.15391/snsv.2021-4.004 


\title{
СЛОБОЖАНСЬКИЙ НАУКОВО-СПОРТИВНИЙ ВІСНИК
}

\begin{abstract}
Alla Semyzorova, Inna Krasova, Kseniia Shevchenko. Generalization of experience in the questions of improving the throwing elements with the hoop of young athletes in rhythmic gymnastics. Purpose: to summarize coaching experience in improving throwing elements with a hoop for gymnasts 7-8 years old. Material and methods: the study involved one hundred twenty athletes 7-8 years old, training at the Rhythmic Gymnastics School of the city of Kharkovand the city of Szczecin. The level of possession of the throwing movements of the hoop was determined using characteristic motor tests and application video recordings. The assessment of the competitive exercise was carried out by the method expert assessments. The experts were coaches with a referee category in rhythmic gymnastics. The result was determined in accordance with the rules of the competition. The maximum score is 10.0 points. Results: the level of mastery of the basic throwing elements with a hoop was revealed for gymnasts of 7-8 years old, the method of error correction was substantiated. The gymnasts received the lowest marks in the following tests: "Throwing a hoop lying on the floor with a swing of the foot with rotation around the diametrical axis of the apparatus on a sideways turnover, catching a jump through the hoop ( $\bar{X}-6,2$ points); «Throw from a spin in the lateral plane with the left hand» ( $\bar{X}-7,0$ points); "Throw with a swing of a horizontally located hoop, catching in the passage in a sideways flip» ( $\bar{X}-7,5$ points). Conclusions: the lowest results were obtained when performing the elements of «difficulties», «risks», «skill» and when performing throws with the left hand. The result for performing a competitive exercise with a hoop is 7,2 points. The repeated results of throwing actions with a hoop increased from $7 \%$ to $31 \%$ and ranged from 8,1 points to 9,5 points. For the performance of a competitive exercise with a hoop, the result increased by $18 \%$ and is 8,5 points.
\end{abstract}

Keywords: hoop, gymnastics, artistic, throws, experience, coach, correction.

\section{References}

1. Agostini, B. R., Novikova, L. A. (2014), «Reliability of execution of throwing elements without visual control in rhythmic gymnastics», Fizicheskaya kultura: vospitanie, obrazovanie, trenirovka: Detskiy trener: zhurnal v zhurnale, № 5, pp. 45-46 (in Russ.)

2. Andrieieva, R. I. (2011), Tekhnolohiia navchannia tekhniky vprav z obruchem na osnovi spetsialnoi fizychnoi pidhotovky yunykh himnastok: avtoref. dys. na zdobuttia nauk. stupenia kand. nauk z fiz. vykhovannia ta sportu : spets. 24.00.01 / Kharkiv, 20 p. (in Ukr.).

3. Andreeva, N. O. (2011), «Improving the technique of teaching the technique of throws and catching gymnastic objects at the stage of specialized basic training", Fizicheskoe vospitanie studentov tvorcheskih spetsialnostey, № 4, pp. 3-5 (in Russ.)

4. Bilokopytova, Zh. A., Nesterova, T. V, Deriuhina, A. M, Bezsonova, V. A. (1999), Khudozhnia himnastyka. Navch. prohr. dlia dytiacho-yunatskykh sportyvnykh shkil, spetsializovanykh dytiacho-yunatskykh shkil olimpiiskoho rezervu, shkil vyshchoi sportyvnoi maisternosti. Kyiv, 115 p. (in Ukr.).

5. Kraeva, E. S., Stepanova, I. A. (2017), «The relationship between the quality of throws fulfillment in group exercises of rhythmic gymnastics with the special motor abilities of female athletes», Uchenyie zapiski universiteta im. P.F. Lesgafta, №1(143), pp. 95-98 (in Russ.)

6. Lenyshyn, V., Sosina, V. (2014), «Features of judging group and individual exercises in rhythmic gymnastics», Sportyvna nauka Ukrainy, №5 (63), pp. 41-46. (in Ukr.).

7. Lisitskaya, T. S., Novikova, L. A. (2017), «Teaching complex throwing elements in rhythmic gymnastics», Fundamentalnyie i prikladnyie issledovaniya fizicheskoy kulturyi, sporta: traditsii i innovatsii: materialyi I Vserossiyskoy nauchno-prakticheskoy konferentsii. Moskva, pp. 485-493. (in Russ.)

8. Markova, O. V., Vynohradova, L. S. (2018), «Biomechanical characteristics of elements of sports exercises technique in rhythmic gymnastics», Fizychne vykhovannia i sport v navchalnykh zakladakh Ukrainy na suchasnomu etapi: stan, napriamky ta perspektyvy rozvytku: zb. nauk. prats KhKhIV Vseukrainskoi naukovo-praktychnoi konferentsii Tsentraln. ukr. derzh. ped. un-tu im. V. Vynnychenka / TsDPU im. V. Vynnychenka. Kropyvnytskyi; Kharkiv: FOP Ozerov H. V. Vyp. 24, pp. 261-265. (in Ukr.).

9. Mullahildina, A. Ya., Shevchenko, K. O. (2014), «Correction of throwing ball movements in athletes 7-9 years in rhythmic gymnastics», Fizychna kultura, sport ta zdorovia: materialy 14-y Mizhnarodnii naukovo-praktychnoi konferentsii, KhDAFK, pp. 104-108 (in Ukr.).

10. Mullahildina, A. Ya., Krasova I. V. (2018), «Technical training of athletes 10-11 years in rhythmic gymnastics in exercises with clubs", Naukovyi chasopys Natsionalnoho pedahohichnoho universytetu imeni MP Drahomanova. Seriia 15: Naukovopedahohichni problemy fizychnoi kultury (fizychna kultura i sport), №. 4, pp. 114-118 (in Ukr.).

11. Tekhnichnyi komitet z khudozhnoi himnastyky: FIG (2017), Pravyla zmahan z khudozhnoi himnastky (2017-2020). URL: http://vfrg.ru/upload/iblock/dbf/dbf6d760bc71ff64006d3431e5734407.pdf (in Ukr.).

12. Topol, H. A. (2017), Kompleksna otsinka pidhotovlenosti kvalifikovanykh sportsmenok u khudozhnii himnastytsi [Comprehensive assessment of qualified training female athletes in rhythmic gymnastics:]: avtoref. dys.. kand. nauk z fiz. vykhovannia i sportu: spets. 24.00.01" Olimpiiskyi ta profesiinyi sport» Nats. un-t fiz. vykhovannia i sportu Ukrainy. Kyiv, 24 p. (in Ukr.).

13. Hudozhestvennaya gimnastika (2003): uchebnik dlya trenerov, prepodavateley i stud. fiz. kulturyi / Vseros. federatsiya hudozhestven. gimnastiki; SPbGAFK im. P.F. Lesgafta; pod red. L.A. Karpenko. M., 384 p. (in Ukr.).

14. Agostini, B. R., Novikova, L. A. (2014), «Identification of factors affecting the implementation jf elements of release with no eye contact in rhythmic in athletes oft he city of fortress», Journal of international federation of physical education, № 84, pp. 128-130 (in Eng.)

15. Andreieva, N, Zhyrnov, O. (2019), «Features of the kinematic structure of throwing technique and catching ball in artistic gymnastics at the stage of preliminary basic training», Theory and Methods of Physical education and sports, №3, pp. 70-73 DOI:10.32652/tmfvs.2019.3.70-73 (in Eng.)

16. Mullagildina, A., Krasova, I. (2019), «Improving the technical training of athletes 10-11 years old in rhythmic gymnastics in exercises with clubs», Slobozhanskyi herald of science and sport, №. 1 (69), pp. 19-24. (in Eng.)

Received: 02.08.2021.

Published: 31.08.2021. 


\section{СЛОБОЖАНСЬКИЙ НАУКОВО-СПОРТИВНИЙ ВІСНИК}

\section{Відомості про авторів / Information about the Authors}

Семизорова Алла Ядікарівна: к.пед.н., доцент; Харківська державна академія фізичної культури: вул. Клочківська, 99, м.Харків, 61058, Україна.

Семизорова Алла Ядикаровна: к.пед.н., доцент; Харьковская государственная академия физической культуры: ул. Клочковская 99, г. Харьков, 61058, Украина.

Alla Semyzorova: PhD (Pedagogical), Associate Professor; Kharkov State Academy of Physical Culture: Klochkivska 99, Kharkov, 61058, Ukraine.

ORCID: https://orcid.org/0000-0002-9232-6387

E-mail: mullagildinaalla@gmail.com

Красова Інна Вікторівна: Харківська державна академія фізичної культури: вул. Клочківська 99, м. Харків, 61058, Україна. Красова Инна Викторовна: Харьковская государственная академия физической культуры: ул. Клочковская 99: г. Харьков, 61022, Украина.

Inna Krasova: Kharkov State Academy of Physical Culture: Klochkivska 99, Kharkov, 61058, Ukraine.

ORCID: https://orcid.org/0000-0002-8111-3917

E-mail: gimnastics.krasova@gmail.com

Шевченко Ксенія Олександрівна: Спортивний Клуб «Академія гімнастики Кристал»; м. Щецин, вул. Лангевича 23/6, 70263, Польща.

Шевченко Ксения Александровна: Спортивный Клуб «Академия гимнастики Кристалл»; ул. Лангевича 23/6, г. Щецин, 70263, Польша.

Kseniia Shevchenko: Sports Club «Gymnastics Academy Crystal»; Langiewicza 23/6, 70263, Szczecin, Poland.

ORCID: https://orcid.org/0000-0002-1673-3052

E-mail: uks.crystal@gmail.com 